\title{
Food Selection-II
}

\author{
For Rational and Economical Living
}

By C. F. Langworthy $\dagger$

Concluded from Scientific American Supplement No. 2100, Page 211, April 1, 1916

IN ITS studies of methods for imparting information throush its extension and other activities, the Department of Asriculture has endeavore to classify common foods in a way corresponding to their distinctive functions in nutrition. The division must be more or less arbitrary, for some foods could go almost equally well in two or more groups. Thus milk, which is a general food, is included with the protein foods because it is a valuable source of this nutrient. Bread is a carbohydrate food, a protein food, and an ash-yielding food, but it is classed as a carbohydrate food because its most obvious constituent is starch, and because we use it in the same seneral way as we starchy foods like potatoes. The classification as now arrange consists of five groups, and it is the understanding that each of these groups should be represented, if not at every meal, at least once a day, and that if an excessive number of food materials from any one sroup are used in the course of a day the result is likely to be unsatisfactory from the standpoint of rational dietetics or of taste.

The groups may be described in terms of the dietitian as follows: (1) Foods in which protein bears a higher proportion to fuel value than it does in the well-chosen diet as a whole; (2) those in which fuel value is high in proportion to protein, owing chiefly to the presence of much starch; (3) those in which fuel value is high, owing to the large percentage of fat; $(4)$ those whose chief value is mineral constituents and vegetable acids (the latter important from the standpoint of flaver as well as of body needs); and (5) those which (like the foods in Groups 2 and 3) have a high fuel value, but in this case due to the presence of sugar. From the standpoint of fuel value only, it is obvious that Groups 2 and 5 could be combined. From the standpoint of the well-chosen and palatable meal, on the other hand, they should be kept distinct, since sugar is fre quently as important as a flavor as it is as a food.

In housekeepers' terms the groups may be described as: (1) Flesh foods (except the very fattest), milk, cheese, egss and such meat substitutes as dried beans, peas, and other-legumes, and some of the nuts; (2) starchy foods; (3) fat foods; (4) watery fruits and vegetables (excluding dried lesumes and fruits which have been dried or comlined with much sugar); and (5) sweets.

The grouping is easy to remember and provides a suide for the housekeeper in the selection of food materials for a meal or for a day's ration and also a means of checking up and criticising the meals which have been served.

It is obvious that while some foods belong clearly to one group, sugar and honey to Group 5, for example and liver and veal (which contain very little fat) clearly

The following sets of menus contain none but wholesome and desirable food materials. These food materials, however, have been poorly combined so far as the protein, fat, and carbohydrate which they provide are concerned. The first set is characterized by much protein, the second set by much fat, and the third set by much carbohydrate.

MENUS WITH PROTHIN PREDOMINATING.

Breakfast-Cereal cooked in milk, chicken hash with egs, popovers, butter and milk as a beverage.

Jinner-Dried-lean purée, halibut steak, potatoes scal-

loped in milk, tomatoes stuffed with chopped beef bread and butter, and frozen custard with nut cookies.

Lunch or Supper-Baked beans, nut bread and butter, old-fashioned rice pudding, and a slass of milk.

The following shows a day's menus (not at all unusual or peculiar) in which fat foods predominate. MENUS WITH FAT PREDOMINATING.

Breakfast-atmeal with cream, sausage, and corn bread and butter.

Dinner-Cream of tomato soul, mutton chop with creamed potatoes, greens cooked with bacon or pork, bread, and suet pudding with hard sauce.

Junch or Supper-Creamed salmon, lettuce with oil dressing, tea biscuits and butter, pumpkin pie, and cup of chocolate.

The following is an example of three meals of combinations common enough, but in which carbohydrat (starch and sugar) predominates. MENUS WITH CARBOHYDRATE PREDOMINATING.

Breakfast-An orange followed by corn cakes with maple syrup, and bread or toast and butter.

Dinner-Meat pie and baked potato, sreen peas, bread and butter, and cottage pudding with chocolate sauce.

Lunch or Supper-Rice croquettes with jelly, rye bread and butter, baked apples, and sugar cookies.

The food and fuel values of the menus served ar given below, the portions served being of the averag and usual size for an adult.

Described in technical terms, for the benefit of the dietitian, the first day's menu supplies 4.2 srammes of protein per 100 calories of energy, or 2,356 calories of energy per 100 grammes of protein; the meals of th fatty menu, 2.4 grammes of protein per 100 calories of energy, or 4,120 calories of energy per 100 grammes of protein; and the meals of the starchy (carbohydrate) menu, 2.5 grammes of protein per 100 calories of enersy, or 4,081 calories of energy per 100 grammes of protein Speaking in terms of the housekeeper: Into the first day's menu there went sixteen food materials othe than fresh fruits and vegetables, of which nine were (All five groups should be represented in the diet every day.)

\begin{tabular}{|c|c|c|c|c|}
\hline Group 1. & Group 2. & Group 3. & Group 4. & Group 5. \\
\hline $\begin{array}{c}\text { Foods Characterized } \\
\text { by Protein. }\end{array}$ & $\begin{array}{l}\text { Foods Characterized } \\
\text { by Starch and Similar } \\
\text { Carbohydrates. }\end{array}$ & $\begin{array}{c}\text { Foods Characterized } \\
\text { by Fat. }\end{array}$ & $\begin{array}{l}\text { Foods Characterized } \\
\text { by Mineral Substances } \\
\text { and Organic Acids. }\end{array}$ & $\begin{array}{l}\text { Foods Characterized } \\
\text { by Sugars. }\end{array}$ \\
\hline $\begin{array}{l}\text { Lean meats } \\
\text { Poultry } \\
\text { Fish } \\
\text { Oysters, etc. } \\
\text { Milk } \\
\text { Cheese } \\
\text { Eggs } \\
\text { Dried legumes } \\
\text { Nuts } \\
\text { And other protein-rich } \\
\text { foods }\end{array}$ & $\begin{array}{l}\text { Bread } \\
\text { Crackers } \\
\text { Macaroni } \\
\text { Rice } \\
\text { Cereal breakfast foods, } \\
\text { meals and flours }\end{array}$ & $\begin{array}{l}\text { Butter } \\
\text { Cream } \\
\text { Lard and other culinary } \\
\text { fats } \\
\text { Salt pork } \\
\text { Bacon } \\
\text { Chocolate }\end{array}$ & $\begin{array}{l}\text { Spinach } \\
\text { Peas } \\
\text { Lettuce } \\
\text { Potatoos } \\
\text { Turnips } \\
\text { Apples } \\
\text { Oranges } \\
\text { Berries } \\
\\
\text { And other vegetables and } \\
\text { fruits, raw or cooked }\end{array}$ & $\begin{array}{l}\text { Syrup } \\
\text { Honey } \\
\text { Jellies } \\
\text { Dried truits } \\
\text { Candy }\end{array}$ \\
\hline
\end{tabular}

to Group 1, other foods are difficult to classify. Mutton, for example, is a protein food which might also be classed as a fat food, and dried navy beans might be classed as a protein and also as a starchy food. To cite another example, potatoes, which are an important source of mineral substance, with some organic acid, are include in Group 4 rather than in Group 2, which at first thought might seem the more logical place for them when we recall that they are so senerally used as a source of carbohydrate (starch). In general, however, the system of groupings will be found helpful.

* The Scientific Monthly.

$\uparrow$ Chief, Office of Home Economics, State Regulations Service,

U. S. Department of Agriculture. from Group 1. Milk entered into or made up ten dishes: egss, four; nuts, two; and beef, tish, chicken, dried beans, and dried peas, each, one. Into the second day's menu went nineteen food materials other than fresh fruits and vesetables, of which nine were distinctly fatty foods (lard, oil, butter, cream, salt pork, and others), while the meat, fish, and even the cereal chosen were those which contained comparatively high percentages of fat. Into the third's day's rations went eleven food materials, of which six were starchy or sugary (rye, wheat, corn, rice, maple syrup, cane sugar) Thus, by unise choice one characteristic of th well-chosen diet-a right proportion between protein and fuel-was omitted.
THE COMPOSITION OF THE NUTRIENTS AND THE ENERGY SUPPLIED BY THE MENUS USED FOR

\begin{tabular}{|c|c|c|c|c|c|}
\hline & $\begin{array}{c}\text { Weight } \\
\text { of Edible } \\
\text { Food } \\
\text { Served, } \\
\text { Grams. }\end{array}$ & $\begin{array}{l}\text { Protein } \\
\text { Grams. }\end{array}$ & $\begin{array}{c}\text { Fat } \\
\text { Grams. }\end{array}$ & $\begin{array}{c}\text { Carbo- } \\
\text { hydrates. } \\
\text { Grams. }\end{array}$ & $\begin{array}{c}\text { Fuel } \\
\text { Value, } \\
\text { Calories }\end{array}$ \\
\hline Protein meals: & & & & & \\
\hline Breakfast... & 471 & 36 & 50 & 54 & 810 \\
\hline Dinner........ & 772 & 58 & 64 & 120 & 1,288 \\
\hline Lunch or supper & 639 & 33 & 38 & 105 & 894 \\
\hline Total....... & 1,882 & 127 & 152 & 279 & 2.992 \\
\hline Fatty meals: & & & & & \\
\hline Breakfast. & 353 & 24 & 69 & 58 & 949 \\
\hline Dinner......... & 617 & 33 & 88 & 108 & 1,356 \\
\hline Lunch or supper & 621 & 29 & 83 & 98 & $\begin{array}{l}1.259 \\
-10\end{array}$ \\
\hline Total. ... & 1,591 & 86 & 240 & 264 & 3,564 \\
\hline $\begin{array}{l}\text { Carbohydrate } \\
\text { Meals. }\end{array}$ & & & & & \\
\hline Breakfast... & 509 & 15 & 32 & 168 & 1,020 \\
\hline Dinner.......... & 529 & 40 & 33 & 133 & 989 \\
\hline Lunch or supper & 376 & 14 & 27 & 127 & 807 \\
\hline Total. . & 1,414 & 69 & 92 & 428 & 2,816 \\
\hline
\end{tabular}

It is hardly necessary to say that different combinations of vegetables and fruits may be made in which the proportion of mild vegetable acids and ash to the other nutrients in the total diet may vary widely - a fact which could be shown by similar groupings of food materials into menus.

To benefit by well-selected menus, each member of the family should eat all of the kinds of food provided, for, if a person habitually eliminates some particular sort of food as fruits and green vegetables, he has failed to take advantage of the housekeeper's selection, no matter how good it may be. One must, speaking broadly, relish all kinds of food, which is a matter of good habits and good manners as well as of physiological importance.

The housekeeper who will learn the simple classification of foods mentioned above can easily see the relation of the different sroups of foods to the character of the meals she provides. She need only go a step further to realize that it is wiser to provide dishes varied in character for a siven meal, and also meals varying from those of the same day and varying from day to day. She can do this easily by taking care to see that the different food groups are represented in at least two of the three meals she serves each day. The more extended her information as to market facilities, the wider her knowledse of standards of quality, the wiser her selection of foods, and the sreater her skill in preparing and cooking them, the easier it will be for her to plan meals by this or any other method, which will be reasonable, economical and satisfactory, as well as adequate.

She can understand also that it is more important to apply the principle outlined to a considerable period of time than to a single day. A departure from the ideal for a day or so means little, for it can be made up the next day or the next week, while an irrational diet, if followe for a long period, may lead to marked disturbance or even serious illness.

The housekeeper need not go into the reasons for all these things which she has to attend to, but she will be ruick to see in a seneral way the point of it all in so far as it concerns her problem of preparing suitable meals for her family. She need not know the theories of electricity to use and appreciate an electric light, nor need she be burdened with the theories of dietetics, if she is willing to trust the conclusions others have reached and apply them to her particular problems.

She naturally wishes for some tangible proof that her efforts to provide a rational diet as part of her ood housekeeping are meeting with success. The general condition of her family should offer her fairly good evidence. Thus, it seems fair to say that the child who continues to approximate the average for his years with respect to weisht and heisht, who is apparently normal in respect to work and play, and who exhibits none of the obvious symptoms of ill health cannot be very faultily fed, any more than can be the adult who remains in fairly constant weight for long periods of time, making due allowance for the seasonal variations (such as the small loss in weight in summer and the small gain in 
winter), and has other attributes of good health. As one reaches middle life it is wise to be more abstemiou in matters of diet, as in other things, for the body is "slowing down" and becoming less active and so need less food. If, in any case, things do not seem to be as they should be, advice should be sought from a physician or other expert, as he alone can judge whether there is an actual departure from normal and whether it is due to diet or to some other cause.

Experience shows clearly that the experimental and the professional worker can be more helpful to the housekeeper than heretofore. The Department of Agriculture is doing what it can to accomplish this important end. The method for translating technical matters of diet into housekeepers' terms, which is outlined above, is an attempt to do this. The method can be modified as experience indicates is desirable, and the
subject-matter can be amended to keep pace with the results of investigation and experiment.

What we can now do to help the housekeeper solve her problems falls short of the ideal, but, at any rate, what has been accomplished would seem sufficient to show her that her problems are recognized as worthy of study, and that an extended and consistent effort is being made to give them the attention they merit. In this movement the United States Department of Agri-

\section{Ancient Principles of Physiognomy*}

THe parent view that mental traits are conditioned by bodilv composition affiliated with views of similar ancestry holding that the traits were revealed in bodily signs, such is the principle of physiognomy, a doctrine story that the physiognømist Zøpyrus, in reading the character of Socrates, pronounced him full of passionate tendencies, thus showing in the epinion of the disciples of Socrates, the vanity of his art. But Socrates came to his defense and confessed the reality of the impulses, which,

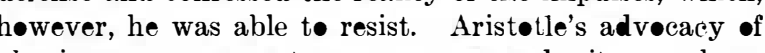
physiognømy was not very pronounced; it may have been little more than an inclination to recognize the reflection of emotion in feature, or the ce-ordinate growth -f body and mind. But the tractate on "Physiognømy" ascribed to him served as the text to the renaissance adepts in eccult lore. Thus restated, even more than in its original setting, it presents the characteristic dependence upøn weak analogy in connecting specific bodily features with specific mental traits. Coarse hair, an erect body, a strong sturdy frame, broad shoulders, a robust neck, blue eyes and dark complexion, a sharp but n॰t large brøw, were together regarded as marks of the courageous man, while the timid man showed opposite
characteristics. The doctrine was re-inforced by such analogies as that timid animals, like the rabbit and the deer, had soft fine hair; while the courageous ones, like the lion and the wild boar, were coarse-haired.

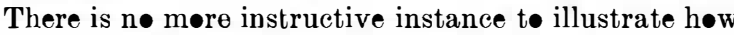
the old learning was reinstated with slight alteration in precept and practice than the career of Jerøme Cardan (1501-1576). Esteemed by his contemporaries, shrewd and able, he was urged in one direction by his taste for science and in another by his credulity. His autøbiegraphy reveals his analytic bent as well as his strong perhis contemporaries thought him wise, we should think him mad; and for what we think him wise, they would have thought hin mad. S• great was his reputation that he was invited and then inveigled to travel from Naples t॰ Scotland to treat the bishøp of St. Andrews. The prelate's ailment had been described as a periedic asthma due te a distillation of the brain inte the lungs, which left a 'temperature and a condition tø møist and tor cold, and the flow of the humors coinciding with the conjunctions and oppositions of the moon." With the characteristic prestige that results from finding others in the wrong, Cardan promptly found that the Archbishøp's

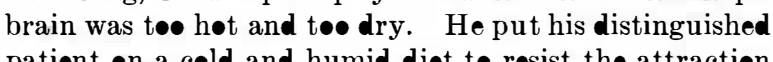
patient $\bullet$ a c cold and humid diet tø resist the attraction or sea-weed, and had water dropped upon his shaven or sea-weed, and had water dropped upon his shaven
crown; in addition, however, he prescribed a regimen of crøwn; in addition, høwever, he prescribed a regimen $\bullet$ f
simple f॰od, much sleep and cold sh॰wers. The imprøvement that resulted-naturally ascribed t• the "humøral" procedures, added much to the glory of Cardan's reputation and the profit of his purse. This physician, learned and wise for his day, was yet the very embodiment of all things superstitiøus. Every trivial •ccurrence was an -men or pøtent. He cast horoscopes, wrote on all manners of cosmic influences, and espoused the rôle of a physiognomist. His distinctive contribution was an astrological physiognømy, based upœn the underlying notion that the furrows or lines of the forehead correhe qualities which they denoted were these connected * Prof. Joseph Jastrow, of the Unlversity of Wlscopaln, in The Scientific Monthiy. with the powers and virtues conferred by Vetius, or Jupiter, or Saturn, or Mercury, etc., in the current astrological system. Across the forehead he drew seven
parallel lines, the spaces in succession dedicated to the moon and the six planets, and by the proportions and prominences of these lines he read the fortune of the subject, n॰t hesitating in $\bullet$ ne case to predict from the grouping of these wrinkles that the owner thereof wa doomed to die by hanging or drowning.

In such manner the humoral doctrine served to de-
ermine the diagnosis of disposition and ailment, while from astrology and physiognomy were drawn further in dications of personal character and probably fortune. Hardly less significant for the logical temper of these pre Harveian days were the contributions of Giøvanni Baptista della Porta (1538-1615). He was impressed by the comparative physiognømy sketched in the Aristetelian writings - a field in turn indicating the strong impression that the traits of animals make upøn the theught-habits -f primitive people; it appears in totemic practises, a

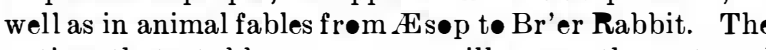
notion that stubborn persons will carry the outward

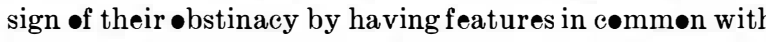
the face of a mule, or that foolish ones will shøw a like resemblance tø a sheep, impresses the modern reader as a strange joke. The analogy will barely support a pleasantry or a metaphor. We are fully conscious of the person mulish, or a shy $\bullet$ e sheepish, or a man of sly way

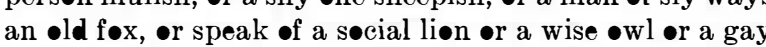
butterfly; it is significant that what was once serious logic is now playful figure of speech. It is alsø in accord with the principle of survivals in culture that the notions made current by generations of credulous "physi-

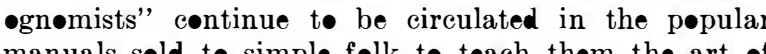

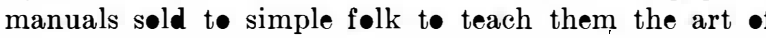
reading faces and futures.

All this would be as irrelevant retrospectively as it is to our central purpose, were it not that it indicates the presence throughout the ages of a considerable body • pøpular lore and systematized doctrine-bøth saturated with flimsy analogy and engaging prepossessions-which in character and its signs in the face, through its best kn॰wn apostle, Jøhann Caspar Lavater (1741-1801) The contrast between Lavater and such men as Cardan and Porta is as marked as that of the spirit and scope $\bullet$ the scientific study of their respective times. The vagaries of the sixteenth century may have stood measurably aloof from the real, if slow and uncertain, advances in the knowledge of mind and nature then maturing; but they were not wholly remote, not wholly tangential to its orbit. This was ne longer true of the eighteenth century. Lavater, despite his reputation and associations and the impesing effect of his ambitious
publications, failed to affect seriously or to divert the publications, failed to affect seriously or to divert the early eighteenth century gave momentum. The scientific contemporaries of Lavater judged his views as critically, appreciated their wholly subjective basis in a personal predilection and their lack of objective warran quite as justly as we of tø-day. The contrast of attitude appears equally in the all but complete desuetude of the - ld persistent pseudo-sciences, astrological and others.

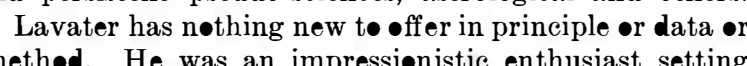
methød. He was an impressionistic enthusiast setting convictions with a minimum of proof. His system was based upon subjective interpretation. His delineation of character has a direct reading of detailed mental traits by an interpretation of their equivalents or representatives in features and expression. Lavater's activities
were manif $\bullet$ ld. Preacher, orat॰r, philanthrøpist, political reformer, dramatist, writer of ballads, he was a conspicuous man of his times, highly regarded by his eminent contemporaries-among them Goethe, whose con-
tribution of the Fragments of Physiognomy have been identified. He was quite without scientific bent or training. Yet his name was so commanding in the annals $\bullet$ physiognømy as to distract attention frøm the slightness of the foundations upon which his elaborate superstructure was raised. Indeed, the impressivenes -f elaborate plates and luxurious editions, and the support of distinguished but uncritical patrons, were re-
sponsible for much of his fame. The reader wh॰ desires sponsible for much of his fame. The reader who desires
first-hand acquaintance with Lavater must be prepared

Nothing less than a glance at the illustrations which the earlier the vagaries of Porta and his lind. They show that what wa
he once pictorial proof has become the artist's pastime. The material presented for amusement in Lear's "Nonsense Botany" or which served Porta as a serious instrument of research. Thus a portrait of Plato is printed side by side with that of a dog, and one of Vitellus Caesar is paralleled hy that of a stag; and in each case
some of the most deserving qualities of the animal are regarded as typical of the human embodiment. Similarly distorted illus trations show human resemblances to a lion, or a bull, or a donkey, or a deer; while the picture of a girl is ungallantly made to approach the features of a plg. These and yet more capriclous
ventures In anlmal physlognomy were Incorporated Into later systoms, often in complete ignorrnce of thetr source. for tedious assertion, for generalities that do not even glitter, for persistent avoidance of real issues, for the futile contention and misunderstanding of a propa-
gandist. Of method he had little, and for the most part translated directly and by use of a dictionary of fanciful etymologies, from the language of a superficial anatømy int that $\bullet$ a whølly arbitrary psychølogy. He presented a pøpular, empirical grøuping of feature-interpretation by virtue of a certain common-sense shrewdness, which he elevated to the dignity of a universal physiognomical sense- "those feelings which are produced at beholding qualities of the mind," which the features suggest. The extensive collection of portraits alone offset the tedium of the text. Lavater was an expert draftsman, and a diligent collector of engravings, outline drawings, and the silhouettes then in vogue. To each picture be attached a character-reading, which reflected little more than his personal impression or knowledge of the subject, t• which ๑ccasionally were added special correlations of such traits as prudence, cunning, industry, caution, determination or what not, with the forehead, the ye, the nose, the mouth, the chin

It was inevitable that the practical interest, lacking the compensations of Lavater's serious purpose, rapidly turned physiognomy int• vulgar quackery. The følby which t๑ interpret the meaning in terms $\bullet$ character, of chin, forehead, eyebrows, and of the several distinctive combinations of feature, by an arbitrary or plausible system of signs. Physiogn less and senseless empiricism. Oblique wrinkles in the forehead were held to indicate an •blique or suspiciøus mind; small eyebrøws with long concave eyelashes were made the sign of phlegmatic melanchølia; long high foreheads were advised not to contract friendships or marriages with spherical heads; such was the decailed but analysis or understanding of facial traits than of mental •nes.

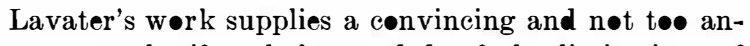
cient example, if such be needed, of the limitations of its utter futility for the purposes of a søund psychølogy; and that apart from the like disqualifications resulting from an ignorance of the significance of such somatic features as those which formed the basis of the system. It sh॰ws høw readily an enthusiastic but unintelligent industry may build a monumental construction upon a hollow foundation. It illustrates as well a specific cance of traits in which we have an interest. It is the general human appeal of the face and its expression and its place in human intercourse that supplies the interest sø readily abused by popular writers or commercial char-
latans. It is just this realm of loose analogy and unchecked ambitious conclusions that attracts feeble minds with a taste for speculation and an inclination for the appease a neglected, the esteric; such a taste, as if tø refuge in a practical semblance of verification. It is this combination of interests that supports physiognomy or phrenology, palmistry or fortune-telling, and (with an altered complexion), Christian Science or Theosephyin which latter examples cures or mirt.

A possible redeeming feature of Lavater's work is his recognition of facial expression as worthy of study; in this he followed the leadership of the artist LeBrun. Expression is much more generic and more readily interpreted than are peculiarities of feature. In such biblical maxims as "though a wicked man constrain his countenance, the wise can distinctly discern his purpose," meaning of expression, sø far as it was pessible before Darwin, he had slight understanding. His physiog-

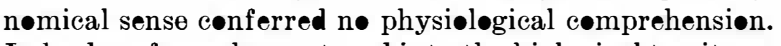
Indeed, sø far as he ventured int the biølogical territøry, he reverted t๑ the older notions, and made fish and f $\bullet$ w
and even insects reveal their character by their effects up॰n the human impression. In an engraving of the heads of snakes he pointed out the reprobate qualities distinguishable in their form, the deceit of their colors, and the naturalness with which we shrink from such a countenance. The logic of physiognemy, ancient or modern, learned or ignorant, is of one kinship; it is the family associations that in time and circumstance come to be less and less respectable.

\section{An Interesting Fact Relating to Cement}

Sand mixed with cement is usually considered as an adulteration, or a diluent, but experiments made at the Arrowrock Dam have shown that a mixture of equal parts Portland cement and sand, when ground together to a very fine state, forms a cement that is practically as strong as clear cement. ' For the general subject I may refer to my volume: "Fact and
Fable In Psychology." 1900 . 